\title{
Gigitan Ular Berbisa
}

\author{
Nia Niasari, Abdul Latief
}

\begin{abstract}
Seorang anak laki-laki, usia 5 tahun 8 bulan dengan diagnosis gigitan ular dengan compartement syndrome dan koagulasi intravaskular diseminata (KID) berdasarkan identifikasi ular yang menggigit dan manifestasi klinis. Presentasi klinis terdiri dari tanda bekas gigitan pada tungkai bawah kanan, rasa nyeri yang makin bertambah , bengkak, ekimosis, bula, compartement syndrome, trombositopenia, anemia, PT, APTT yang memanjang, dan d-dimer yang meningkat. Bila dilihat dari bentuk ular yang menggigit dan manifestasi klinis yang timbul, yaitu bisa ular yang bersifat sitotoksik, ular yang mengigit adalah famili Viperidae. Derajat berat kasus yang terjadi adalah derajat 4 (major), karena terdapat tanda bekas gigitan, edem yang luas, serta KID.

Antibiotik diberikan juga kortikosteroid, bertujuan untuk mencegah efek samping pemberian anti bisa ular. Fasciotomy dilakukan karena terdapat compartement syndrome setelah itu pasien dirawat di ICU Anak untuk pemantauan lebih lanjut dan mempersiapkan apabila diperlukan heparinisasi. Pasien dipulangkan dalam keadaan baik setelah 3 minggu perawatan.
\end{abstract}

Kata kunci: ular berbisa, compartement syndrome, fasciotomy

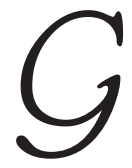

igitan atau sengatan binatang berbisa, seperti ular, laba-laba atau binatang berbisa lainnya, pada umumnya menyebabkan nyeri lokal dan tidak memerlukan perawatan, namun anak-anak mempunyai risiko tinggi terjadi reaksi berat. Reaksi klinis berat pada anak sering terjadi karena volume tubuh lebih kecil untuk penyebaran racun/ bisadibandingkan dengan orang dewasa. ${ }^{1}$

Pada setiap kasus yang dilaporkan sebagai gigitan ular, harus dipastikan apakah gigitan tersebut disebabkan ular berbisa. Hal tersebut dapat ditentukan antara lain dari luka bekas gigitan yang terjadi. Jika identifikasi sulit ditentukan, gejala dan tanda akibat gigitan bisa ular menjadi dasar untuk menegakkan diagnosis. ${ }^{2}$

Dr. Nia Niasari, PPDS Ilmu Kesehatan Anak FKUI, Jakarta

Alamat korespondensi:

Dr. Abdul Latief, Sp.A(K).

Subbagian Pediatri Gawat Darurat Bagian Ilmu Kesehatan Anak FKUIRSCM. Jl. Salemba No. 6, Jakarta 10430.

Telepon: 3914125. Fax.: 3907743.
Dalam menghadapi kasus gigitan ular berbisa diperlukan tata laksana yang cepat, baik dalam menegakkan diagnosis maupun terapinya, oleh karena dapat menimbulkan kecacatan dan mengancam jiwa. ${ }^{3}$

\section{Laporan Kasus}

Seorang anak laki-laki, N, usia 5 tahun 8 bulan dirujuk dari Poliklinik Bedah Instalasi Gawat Darurat RS Dr. Cipto Mangunkusumo Jakarta (RSCM) dengan keterangan digigit ular.

Dari aloanamnesis didapatkan keterangan bahwa kurang lebih 3 jam sebelum masuk IGD RSCM tungkai bawah kanan dekat pergelangan kaki di gigit ular saat pasien sedang berjalan di kebun belakang rumah, bersama dengan ayahnya. Ular tidak diketahui jenisnya (bercorak dan berwarna coklat). Ketika itu pasien langsung menangis karena kesakitan dan ayah pasien melihat dua tanda bekas gigitan ular, bengkak dan kemerahan mulai timbul setengah jam kemudian. Pasien dibawa ke RS H, luka gigitan dibersihkan dan diberikan suntikan TT (toksoid tetanus). selanjutnya 
dirujuk ke RSCM. Selama itu pasien makin merasakan nyeri di tungkai bawah kanan bekas gigitan tampak kemerahan dan bengkak yang semakin besar. Pasien tidak merasakan mual, tidak ada muntah ataupun rasa lemas, mengantuk, kejang dan gatal-gatal pada daerah wajah. Sampai di IGD RSCM, luka gigitan dibersihkan dan diberi suntikan ATS dan serum anti bisa ular (SABU) 2 vial dalam $250 \mathrm{ml}$ Dekstrosa 5\%, kemudian pasien dikonsulkan ke Bagian Anak.

Pada pasien ini tidak didapatkan riwayat asma, alergi obat, alergi makanan, kejang, perdarahan yang sukar berhenti dan tidak ada riwayat biru-biru pada tubuh pasien. Pasien belum pernah digigit binatang berbisa dan mendapat antiracun sebelumnya. Anggota keluarga tidak ada yang menderita kelainan darah.

Pada pemeriksaan fisis didapatkan anak sadar tidak sesak, tidak sianosis. Berat badan $17 \mathrm{~kg}\left(\mathrm{P}_{10-25} \mathrm{NCHS}\right)$, tinggi badan $105 \mathrm{~cm}\left(\mathrm{P}_{3-10} \mathrm{NCHS}\right)$, gizi baik. Tekanan darah 110/80 $\mathrm{mmHg}$, laju nadi 110 kali permenit, isi cukup, teratur, laju pernapasan 28 kali per menit, suhu aksila $36,8^{\circ} \mathrm{C}$. Lingkar kepala $49 \mathrm{~cm}$ (normal), tidak terdapat deformitas, rambut hitam, lurus, tidak mudah dicabut. Pada kulit yang bukan tempat gigitan tidak tampak tanda perdarahan lain.

Konjungtiva tidak pucat, sklera tidak ikterik, refleks cahaya positif dan pupil isokor. Pada telinga, hidung dan tenggorokan tidak ada tanda perdarahan. Tidak didapatkan pembesaran kelenjar getah bening di daerah leher. Perut datar, lemas pada perabaan, turgor cukup, hati dan limpa tidak teraba dan bising usus positif normal. Pada genetalia teraba testis bilateral, fimosis tidak ada. Alat gerak teraba hangat, perfusi perifer baik. Status neurologis tidak didapatkan kelumpuhan syaraf kranialias, motorik maupun gangguan sensoris.

Status lokalis tampak tungkai bawah kanan yang membengkak, dijumpai ekimosis dan bula. (Gambar 1). Bekas gigitan sudah dilakukan insisi untuk membersihkan luka.

Pemeriksaan darah tepi ( $31 / 4$ jam setelah gigitan), kadar hemoglobin 12,5 g/dL, hematoksit $35 \mathrm{vol} \%$, leukosit $23.400 / \mu \mathrm{L}$, trombosit $28.000 / \mu \mathrm{L}$ (duplo), gula darah sewaktu $196 \mathrm{mg} / \mathrm{dL}$, natrium darah $142 \mathrm{mEq} / \mathrm{L}$, kalium darah 3,3 mEq/L, klorida darah 108 mEq/L, PT 28,1 detik (kontrol 11,2 detik), APTT 56,4 detik (kontrol 36,2 detik).

Pasien mendapat pengobatan deksametason $3 \times 1,5$ mg (iv). Suntikan deksametason pertama diberikan 6 $1 / 2$ jam setelah gigitan. Pasien mendapat transfusi FFP (fresh frozen plasma) $180 \mathrm{ml}$ pada $7 \mathrm{jam}$ setelah gigitan. Pemeriksaan EEG normal.
Pemeriksaan darah yang dilakukan 8 jam setelah gigitan menunjukkan PT 30 detik (kontrol 11,2 detik), APTT 51,9 detik (kontrol 36,3 detik), d-dimer kuantitatif 15.100,00 ng/mL (normal 0,00 - 300,00), ureum darah 33 (normal : 20-40 mg/dL), kreatinin darah 0,7 (normal 0,5 - 1,5 mg/dL). Pemeriksaan urinalisis didapatkan sel epitel positif, leukosit 4-6/LPB, eritrosit 5-8/LPB, silinder granula $0-2 / \mathrm{LPK}$, kristal negatif, bakteri negatif, bilirubin positif, urobilinogen 0,2 , nitrit negatif, esterase leukosit negatif. Diagnosis koagulopati intravaskular diseminata (KID) ditegakkan dan pasien diberi transfusi cryopresipitat 350 unit.

Dua belas jam setelah gigitan, pemeriksaan darah perifer $\mathrm{Hb} 8,7 \mathrm{~g} / \mathrm{dL}, \mathrm{Ht} 24$ vol\%, leukosit $9900 / \mu \mathrm{L}$, trombosit $181.000 / \mu \mathrm{L}$. Saat itu direncanakan dilakukan fasciotomy oleh bagian Bedah karena terdapat compartment syndrome cruris dextra dan diberikan sefotaksim 2 × $500 \mathrm{mg}$ (iv).

Fasciotomy dilakukan 15 jam setelah gigitan, pasca operasi pasien dirawat di ICU anak. Pengobatan sebagai berikut, di ICU pasien dipuasakan, diberikan infus dekstrose 5\%: $\mathrm{NaCl} 0,9 \%=3: 1+\mathrm{KCl} 10 \mathrm{mEq} /$ kolf sebanyak $60 \mathrm{ml} / \mathrm{jam}$, tramadol 3 x $15 \mathrm{mg}$ iv dan sefotaksim 3 x $500 \mathrm{mg}$ iv. Pemeriksaan darah pada 25 jam setelah gigitan, $\mathrm{Hb} 5,8 \mathrm{~g} / \mathrm{dL}, \mathrm{Ht} 15$ vol\%, leukosit $1500 / \mu \mathrm{L}$, trombosit $2000 / \mu \mathrm{L}$. Maka pasien mendapatkan transfusi PRC (packed red cell) $200 \mathrm{~mL}$, TC (thrombocyte concentrate) $5 \mathrm{U}$, FFP $170 \mathrm{~mL}$ dan cryopresipitat $375 \mathrm{~mL}$. Selama di ICU dilakukan monitor terhadap kesadaran, tanda vital, perluasan peradangan dan observasi terhadap perdarahan yang mungkin timbul.

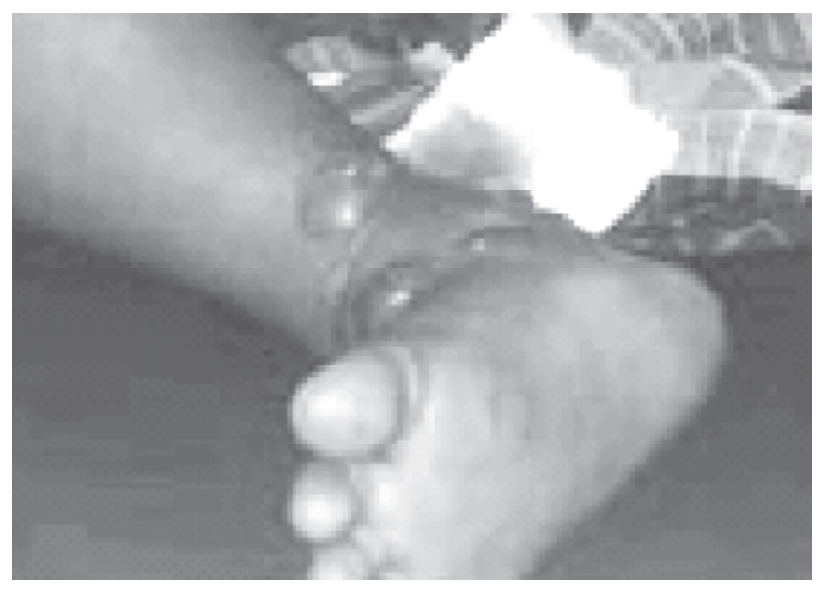

Gambar 1. Tungkai bawah yang terkena gigitan ular berbisa tampak bengkak dan bula 
Pada saat 36 jam setelah gigitan, $\mathrm{Hb} 11,8 \mathrm{~g} / \mathrm{dL}$, Ht 37 vol\%, leukosit $4100 / \mu \mathrm{L}$, trombosit 261.000/ $\mu \mathrm{L}$, hitung jenis (\%) : -/-/-/2/76/21/1, PT 12,2 detik (kontrol 12,5 detik), APTT 37,9 detik (kontrol 38,6 detik), d-dimer kuantitatif $600,00 \mathrm{ng} / \mathrm{mL}$ (normal 0,00 - 300,00), ureum darah $10 \mathrm{mg} / \mathrm{dL}$, kreatinin darah $0,5 \mathrm{mg} / \mathrm{dL}$, mioglobin urin negatif. Hasil konsultasi dengan divisi Hematologi Anak, dikatakan heparinisasi tidak perlu dilakukan, dan cryopresipitat diberikan bila terjadi perdarahan. Pasien mulai mendapatkan diet makanan lunak 1200 kalori.

Selama perawatan di ICU keadaan umum pasien membaik. Pasien di pindah ke perawatan bangsal bedah anak setelah 7 hari dirawat di ICU dan IW (intermediate ward). Tidak ada komplikasi yang timbul baik dari bisa ular atau anti bisa ular. Luka operasi terawat baik dan keadaan tungkai bawah kananpun membaik. Pasien dipulangkan setelah 3 minggu perawatan.

\section{Tinjauan pustaka}

\section{Epidemiologi}

Kasus gigitan ular di Amerika Serikat dilaporkan setiap tahun sekitar 45.000 kasus, namun yang disebabkan oleh ular berbisa hanya 8000 kasus..$^{1-3}$ Selama 3 tahun terakhir, the American Association of Poison Control Centers melaporkan bahwa dari 6000 kasus gigitan ular, 2000 diantaranya merupakan gigitan ular berbisa. ${ }^{2}$ Kematian diperkirakan terjadi pada 5 sampai 15 kasus dan biasanya terjadi pada anak-anak, orang yang lanjut usia, dan pada kasus yang tidak atau terlambat mendapatkan anti bisa ular. ${ }^{2,3}$ Pasien korban gigitan ular berbisa $15 \%$ sampai $40 \%$ akan meninggalkan gejala sisa. ${ }^{4}$ Menurut catatan medik RSCM, kejadian kasus gigitan ular berbisa selama 5 tahun terakhir (1998 - 2002) sebanyak 37 pasien.

Pada umumnya korban gigitan ular adalah lakilaki dengan usia antara 17 sampai tahun, seringkali dalam kondisi mabuk, sedang melakukan aktifitas berkebun, atau sedang menangkap bahkan bermain dengan ular. ${ }^{1,2}$ Waktu gigitan biasanya terjadi pada malam hari dan gigitan lebih sering terjadi pada ekstremitas. ${ }^{3}$ Malik dkk, ${ }^{5}$ pada tahun 1992 melakukan penelitian terhadap korban gigitan ular, mendapatkan tempat gigitan pada tungkai atau kaki $(83,3 \%)$ dan lengan atau tangan $(17,7 \%){ }^{5}$

Terdapat 3000 spesies ular, 200 spesies diantaranya termasuk ular berbisa. ${ }^{1}$ Ular berbisa sebagian besar berasal dari 3 famili yaitu, Hydrophidae (ular laut), Elapidae (contohnya cobra) dan Viperidae (Crotalidae). ${ }^{1}$ Kasus gigitan ular berbisa 95\% disebabkan oleh gigitan ular dari famili Crotalidae.

Ular jenis Crotalidae disebut juga Viperidae atau pit vipers karena kepala berbentuk triangular, pupil matanya elips, serta terdapat lubang antara hidung dan mata. (Gambar 2). Lubang tersebut pada jenis pit viper berfungsi sebagai organ sensoris terhadap panas. ${ }^{1,3} \mathrm{Pit}$ viper mudah dikenal dari taringnya yang cukup panjang, sekitar 3-4 cm. ${ }^{3}$ Jenis ular berbisa dari famili Elapidae misalnya coral snake mempunyai kepala kecil dan bulat, dengan pupil bulat dan taring lebih kecil sekitar 1-3 mm. ${ }^{1,3}$ Coral snake mudah diidentifikasi karena warnanya terang, misalnya belang hitam dan merah atau kuning. ${ }^{6}$

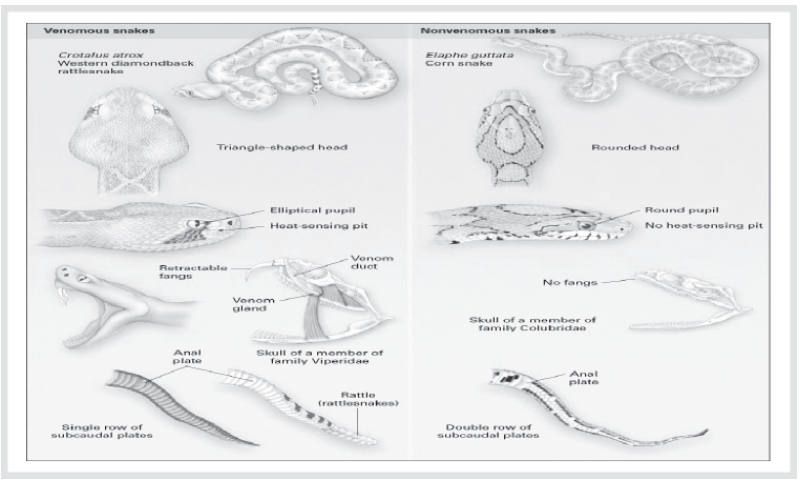

Gambar 2. Gambar ular jenis Crotalidae dan Elapidae

\section{Patofisiologi}

Bisa ular terdiri dari campuran beberapa polipeptida, enzim dan protein. ${ }^{1,6}$ Jumlah bisa, efek letal dan komposisinya bervariasi tergantung dari spesies dan usia ular. Bisa ular bersifat stabil dan resisten terhadap perubahan temperatur. ${ }^{2}$ Secara mikroskop elektron dapat terlihat bahwa bisa ular merupakan protein yang dapat menimbulkan kerusakan pada sel-sel endotel dinding pembuluh darah, sehingga menyebabkan kerusakan membran plasma. ${ }^{2}$ Komponen peptida bisa ular dapat berikatan dengan reseptor-reseptor yang ada pada tubuh korban. ${ }^{2}$ Bradikinin, serotonin dan histamin adalah sebagian hasil reaksi yang terjadi akibat bisa ular. ${ }^{6}$

Enzim yang terdapat pada bisa ular misalnya Larginine esterase menyebabkan pelepasan bradikinin 
sehingga menimbulkan rasa nyeri, hipotensi, mual dan muntah serta seringkali menimbulkan keluarnya keringat yang banyak setelah terjadi gigitan. Enzim protease akan menimbulkan berbagai variasi nekrosis jaringan. Phospholipase A menyebabkan terjadi hidrolisis dari membran sel darah merah. Hyaluronidase dapat menyebabkan kerusakan dari jaringan ikat. Amino acid esterase menyebabkan terjadi KID. ${ }^{6}$ Pada kasus yang berat bisa ular dapat menyebabkan kerusakan permanen, gangguan fungsi bahkan dapat terjadi amputasi pada ekstremitas. $^{7}$

Bisa ular dari famili Crotalidae/Viperidae bersifat sitolitik yang menyebabkan nekrosis jaringan, kebocoran vaskular dan terjadi koagulopati. ${ }^{1}$ Komponen dari bisa ular jenis ini mempunyai dampak hampir pada semua sistem organ. ${ }^{2}$ Bisa ular dari famili Elapidae dan Hydrophidae terutama bersifat sangat neurotoksik, dan mempunyai dampak seperti kurare yang memblok neurotransmiter pada neuromuscular junction. ${ }^{1}$ Aliran dari bisa ular di dalam tubuh, tergantung dari dalamnya taring ular tersebut masuk ke dalam jaringan tubuh. ${ }^{8}$

\section{Klasifikasi}

Derajat berat kasus gigitan ular berbisa umumnya dibagi dalam 4 skala, yaitu derajat 1 (minor) $=$ tidak ada gejala, derajat 2 (moderate) = gejala lokal, derajat 3 (severe) $=$ gejala berkembang ke daerah regional, derajat 4 (major) $=$ gejala sistemik. ${ }^{1,9}$

Tabel 1 ini adalah tabel skor dari derajat beratnya kasus gigitan ular berbisa dari famili Crotalidae dan famili Elapidae.?

Pada umumnya gejala yang ditimbulkan oleh bisa ular terjadi dalam 2-6 jam setelah gigitan. ${ }^{1,10}$ Infark serebri sering terjadi karena gigitan ular dari famili Crotalidae/Viperidae, terjadi dalam waktu 7 jam sampai 1 minggu setelah gigitan. ${ }^{11}$ Lalloo DG $\mathrm{dkk},{ }^{12}$ pada tahun 1992 melaporkan bahwa gejala klinis timbul mulai 15 menit sampai 6 jam (dengan median 1 jam) setelah gigitan. ${ }^{12}$

\section{Manifestasi klinis}

Gigitan oleh Viperidae/ Crotalidae seringkali menimbulkan gejala pada tempat gigitan berupa nyeri dan bengkak yang dapat terjadi dalam beberapa menit, bisa akan menjalar ke proksimal, selanjutnya terjadi edem dan ekimosis. Pada kasus berat dapat timbul bula dan jaringan nekrotik, serta gejala sistemik berupa mual, muntah, kelemahan otot, gatal sekitar wajah dan kejang. Pasien jarang mengalami syok, edem generalisata atau aritmia jantung, tetapi perdarahan sering terjadi. ${ }^{1}$ Boyer LV dkk, ${ }^{13}$ melaporkan bahwa dari 38 korban gigitan ular Viperidae, 29 (76\%) mengalami koagulopati, dengan 20 (53\%) terdapat beberapa kelainan komponen koagulopati (misalnya hipofibrinogenemia dan trombositopenia). ${ }^{13}$

Gigitan akibat Elapidae biasanya tidak menimbulkan nyeri hebat. ${ }^{1,3}$ Namun demikian tidak adanya gejala lokal atau minimal, tidak berarti gejala yang lebih serius tidak akan terjadi. Gejala yang serius lebih jarang terjadi dan biasanya gejala berkembang dalam 12 jam. ${ }^{3}$ Bisa yang bersifat neurotoksik, mempunyai dapat sangat cepat dalam beberapa jam, mulai dari perasaan mengantuk sampai kelumpuhan nervus kranialis, kelemahan otot dan kematian karena gagal napas. ${ }^{1}$

Pemeriksaan laboratorium biasanya menunjukkan peningkatan jumlah neutrofil, limfopenia, koagulopati dengan PT dan PTT memanjang, serta penurunan jumlah fibrinogen. Kadar kreatinin kinase serum normal pada hari pertama dan kedua setelah perawatan. Mioglobin plasma dan kadar kreatinin mempunyai korelasi yang kuat. ${ }^{12}$ Pada pemeriksaan urinalisis dapat terjadi proteinuria $(83 \%)$, serta hematuria mikroskopik $(50,9 \%)$. Hemoglobinuria dan mioglobinuria umumnya dapat dideteksi dan dapat terjadi leukosituria (56,4\%). ${ }^{12}$ Penelitian Ramachandram S dkk, 14 pada tahun 1995 mendapatkan kadar $\mathrm{Hb}$ dan leukosit normal pada semua pasien, 3\% terjadi trombositopenia $(<75.000 / \mu \mathrm{L})$. Kadar ureum darah meningkat pada pasien dengan gejala gagal ginjal. Natrium, kalium, klorida, calsium, serta glukosa darah masih dalam batas normal pada semua pasien. ${ }^{14}$

Hasil EEG abnormal ditemukan pada 96\% dan berhubungan dengan ukuran ular, tetapi tidak berhubungan dengan derajat beratnya penyakit di lokasi gigitan, adanya manifestasi neurologis atau keadaan gagal ginjal. ${ }^{14}$ Perubahan EEG segera terjadi setelah gigitan dan akan kembali normal dalam 1-2 minggu. ${ }^{14}$ Pada pemeriksaan EKG, umumnya terjadi kelainan seperti bradikardia dan inversi septal gelombang T. Hasil EKG yang abnormal termasuk tanda-tanda utama gejala gigitan ular berbisa, selain perdarahan, koagulopati dan paralisis. ${ }^{12}$ 
Tabel 1. Klasifikasi gigitan ular berbisa

\begin{tabular}{|c|c|c|c|c|}
\hline & Famili $C r$ & talidae $^{9}$ & & Famili Elapidae ${ }^{6}$ \\
\hline Derajat & Derajat & Gejala dan tanda & Derajat & Gejala dan tanda \\
\hline 1. & Minor & $\begin{array}{l}\text { Tredapat tanda bekas } \\
\text { gigitan / taring, tidak } \\
\text { ada edem, tidak nyeri, } \\
\text { tidak ada gejala sistemik, } \\
\text { tidak ada koagulopati. }\end{array}$ & 0 -none & $\begin{array}{l}\text { Riwayat digigit ular, } \\
\text { pembengkakan lokal } \\
\text { dengan tanda guratan, } \\
\text { tidak ada gangguan } \\
\text { neurologis }\end{array}$ \\
\hline 2. & Moderate & $\begin{array}{l}\text { Terdapat tanda bekas } \\
\text { gigitan/taring, edem } \\
\text { lokal, tidak ada gejala } \\
\text { sistemik, tidak ada } \\
\text { koagulopati }\end{array}$ & 1 - moderate & $\begin{array}{l}\text { Derajat } 0 \text { ditambah } \\
\text { gejala neurologis atau } \\
\text { disertai eforia, mual, } \\
\text { muntah, parestesia, } \\
\text { ptosis, kelemahan otot, } \\
\text { paralisis, sesak }\end{array}$ \\
\hline 3. & Severe & $\begin{array}{l}\text { Terdapat tanda bekas } \\
\text { gigitan, edem regional } \\
\text { ( } 2 \text { segmen dari ekstremitas), } \\
\text { nyeri yang tidak teratasi oleh } \\
\text { analgesik, tidak ada tanda } \\
\text { sistemik, teradapat tanda } \\
\text { koagulopati. }\end{array}$ & 2 - severe & $\begin{array}{l}\text { Gejala pada derajat } 1 \\
\text { ditambah paralisis otot } \\
\text { pernapasan dalam } 36 \\
\text { jam pertama }\end{array}$ \\
\hline 4. & Major & $\begin{array}{l}\text { Terdapat tanda bekas gigitan, } \\
\text { edem yang luas terdapat tanda } \\
\text { sistemik (muntah, sakit kepala, } \\
\text { nyeri pada perut dan dada, syok), } \\
\text { trombosis sistemik }\end{array}$ & & \\
\hline
\end{tabular}

\section{Diagnosis}

Diagnosis definitif gigitan ular berbisa ditegakkan berdasarkan identifikasi ular yang menggigit dan adanya manifestasi klinis. Ular yang menggigit sebaiknya dibawa dalam keadaan hidup atau mati, baik sebagian atau seluruh tubuh ular. Perlu juga dibedakan apakah gigitan berasal dari ular yang tidak berbisa atau binatang lain, dari pemeriksaan fisik pada luka gigitan yang ditinggalkan. Bila tidak dapat mengidentifikasi ular yang menggigit, manifetasi klinis menjadi hal yang utama dalam menegakkan diagnosis. ${ }^{2}$

\section{Terapi}

Terapi yang dilakukan terbagi menjadi tata laksana di tempat gigitan dan di rumah sakit. Tata laksana di tempat gigitan termasuk mengurangi atau mencegah penyebaran racun dengan cara menekan tempat gigitan dan imobilisasi ekstremitas. ${ }^{15,16}$ Selain itu diusahakan transportasi yang cepat untuk membawa pasien ke rumah sakit terdekat, pasien tidak diberikan makan atau minum. Saat ini eksisi dan penghisapan bisa tidak dianjurkan bila dalam 45 menit pasien dapat sampai di rumah sakit. ${ }^{6}$

Di rumah sakit diagnosis harus ditegakkan dan segera pasien dipasang dua jalur intravena untuk memasukkan cairan infus dan jalur yang lain disiapkan untuk keadaan darurat. Segera dilakukan pemeriksaan laboratorium seperti darah perifer lengkap, PT, APTT, fibrinogen, elektrolit, urinalisis dan kadar ureum serta kreatinin darah. Pasien diberikan suntikan toksoid tetanus dan dipertimbangkan pemberian serum anti bisa ular. Pengukuran pada tempat gigitan perlu dinilai untuk mengetahui progresivitasnya. Kadang perlu dilakukan eksisi dan penghisapan bisa pada saat luka dibersihkan. Saat ini masih diperdebatkan tentang tindakan operasi (fasciotomy) pada pasien gigitan ular berbisa. Fasciotomy dilakukan bila ada edem yang makin luas dan terjadi compartment syndrome (keadaan iskemik berat pada tungkai yang mengalami revaskularisasi dan 
menimbulkan edem, disebabkan peningkatan permeabilitas kapiler dan keadaan hiperemia). Pada semua kasus gigitan ular, perlu diberikan antibiotik spektrum luas dan kortikosteroid, meskipun pemberian kortikosteroid masih diperdebatkan. ${ }^{6}$

Di Amerika hanya terdapat 3 anti bisa yang diproduksi dan disetujui oleh FDA, yaitu antivenim polyvalen crotalidae, antivenon untuk coral snake (Elapidae) dan antivenon untuk black widow spider. ${ }^{1}$ Semua anti bisa ular adalah derivat serum binatang, tersering berasal dari serum kuda, berupa imunoglobulin yang mengikat secara langsung dan menetralkan protein dari bisa. Produk hewan ini bila terpapar pada pasien dalam jumlah besar dapat menyebabkan reaksi hipersensitifitas tipe cepat dan tipe III. Reaksi akut berupa reaksi anafilaktik dapat terjadi pada $20-25 \%$ pasien, bahkan dapat terjadi kematian karena hipotensi dan bronkospasme. Reaksi tipe lambat dapat terjadi pada $50-75 \%$ pasien dengan gejala serum sickness seperti demam, ruam yang difus, urtikaria, artralgia, hematuria dan dapat bertahan dalam beberapa hari. ${ }^{4}$ Reaksi yang paling sering terjadi adalah urtikaria, namun efek samping yang serius jarang terjadi. ${ }^{17}$ Pemberian anti bisa ular harus dilakukan di rumah sakit yang tersedia alat-alat resusitasi. ${ }^{1}$ Penggunaan adrenalin, steroid dan antihistamin dapat mengurangi reaksi yang terjadi akibat anti bisa antara $12,5-30 \% .{ }^{18}$ Profilaksis yang hanya menggunakan promethazine tidak dapat mencegah reaksi yang cepat. ${ }^{19}$ Anak-anak lebih sering memerlukan jumlah data anti bisa yang banyak oleh karena kecilnya rasio antara volume tubuh dan bisa ular yang terdistribusi. 1

Pada tahun 2000 bulan Desember terdapat produk baru yaitu Crotalinae Polyvalent Immune Fab (ovine) antivenon yang berasal dari serum domba. Serum Fab ini ternyata lima kali lebih poten dan efektif sebagai anti bisa dan jarang terdapat komplikasi akibat pemberiannya. Penggunaan serum Fab dianjurkan diencerkan dalam $250 \mathrm{ml} \mathrm{NaCl}$ 0,9\% dan pemberiannya lebih dari satu jam melalui intravena. Untuk pasien yang masih sangat kecil (berat badan kurang dari $10 \mathrm{~kg}$ ), volume cairan dapat disesuaikan. Jumlah penggunaan anti bisa ular tergantung derajat beratnya kasus. Kasus dengan derajat none tidak diberikan anti bisa, untuk kasus dengan derajat minimal diberikan 1-5 vial sedangkan moderate dan severe lebih dari 15 vial. $^{6}$

Antibiotik diberikan secara rutin, karena dapat terjadi infeksi pada tempat gigitan. Pemberian antibiotik masih kontroversi, namun Blaylock tahun 1999 dari penelitiannya mendapatkan 18 diantara 20 pasien mempunyai biakan darah positif bakteria gram negatif aerob. ${ }^{20}$

\section{Prognosis}

Gigitan ular berbisa berpotensi menyebabkan kematian dan keadaan yang berat, sehingga perlu pemberian antibisa yang tepat untuk mengurangi gejala. Ekstremitas atau bagian tubuh yang mengalami nekrosis pada umumnya akan mengalami perbaikan, fungsi normal, dan hanya pada kasus-kasus tertentu memerlukan skin graft.

\section{Daftar pustaka}

1. Holve S. Envenomation. Dalam: Behrman RE, Kliegman RM, Jenson HB, penyunting. Nelson textbook of pediatrics. Edisi ke-16. Philadelphia : WB Saunders company, 2000. h. 2174-8.

2. Gold BS, Dart RC, Barish RA. Bites of venomous snakes. N Engl J Med, 2002; 347:347-56.

3. Roberts JR, Otten EJ. Snakes. Dalam: Goldfrank LR, Flomenbaum NE, Lewin NA, Weisman RS, Howland MA, penyunting. Toxicologic emergencies. Edisi ke-4. Connecticut: Prentice - Hall International Inc, 1990. h. 789-99.

4. Dart RC, Seifert SA, Boyer LV, Clark RF, Hall E, McKinney P, dkk. A randomized multicenter trial of crotalinae polyvalent immune Fab (ovine) antivenom for the treatment for crotaline snakebite in the Unites States. Arch Intern Med 2001; 161:2030-6.

5. Malik GM. Snake bites in adults from the Asia region of Southern Saudi Arabia. Am J Trop Med Hyg 1995; 52:314-7.

6. Snyder CC, Mayer TA. Animal, snake, and insect bite. Dalam: Matlak ME, Nixon GW, Walker ML, penyunting. Emergency management of pediatric trauma. Edisi ke-1. Philadelphia: WB Saunders Company. 1985. h. 466-83.

7. Boechat ALR, Paiva CS, Franca FO, Dos-Santos MC. Heparin-antivenom association: differential neutralization effectiveness in bothrops atrox and bothrops erythromelas envenoming. Rev Inst Med trop S Paulo 2001; 43:1-16.

8. Young BA, Zatin K. Venom flow in rattlesnake: mechanics and metering. J of Exp Biol 2001; 204:4345-51.

9. Thomas L, Tyburn B, Bucher B, Pecout F, Ketterle J, Rieux $\mathrm{D}$, dkk. Prevention of thromboses in human patients with bothrops and anceolatus envenoming in martinique: Failure of anticoagulants and efficacy of a monospecific antivenom. Am J Trop Med Hyg 1995; 52:419-26.

10. Seneviratne U, Dissanayaka S. Neurological manifesta- 
tion of snake bite in Sri Lanka. Journal of Postgraduate Medicine 2002; 48:275-9.

11. Numeric P, Moravie V, Didier M, Chatot0Henry D, Cirille S, Bucher B, dkk. Multiple cerebral infarctions following a snikebite by bothrops caribbaeaus. Am J Trop Med Hyg 2002; 67:287-8.

12. Lallo DG, Trevett AJ, Korinhona A, Nwokolo N, Laurenson IF, Paul M, dkk. Snake bites by the papuan taipan (Oxyuranus scutellatus canni): paralysis, hemostatic and electracardiographic abnormalities, and effects of antivenom. Am J Trop Med Hyg 1995; 52:525-31.

13. Boyer LV, Siefert SA, Clark RF, McNally JT, Williams SR, Nordt SP, dkk. Recurrent and persistent coagulopathy following pit viper envenomation. Arch Intern Med 1999; 159:706-10.

14. Ramachandran S, Ganaikabahu B, Pushparajan K, Wijesekera J. Electroencephalographic abnormalities in patients with snake bites. Am J Trop Med Hyg 1995; 52:25-8.

15. Tun-Pe, Aye-Aye-Myint, Khin-Ei-han, Thi-Ha, Tin-NuSwe. Local compression pads as a first-aid measure for victims of bites by Russell's viper (Daboia russelii siamersis) in myanmar. Transactions of the Royal Soc of
Trop Med and Hyg 1945; 89:293-5.

16. Tun-Pe, Sann-Mya, Aye-Aye-Myint, Nu-Nu-Aung. KhinAye-Kyu, Tin-Oo. Field trial of officacy of local compression immobilization firts-aid technique in russell's viper (Daboia russelii siamensis) bite patients. Southeast As J Trop Med Public Health 2000; 31:346-8.

17. Offerman SR, Smith TS, Derlet RW. Does the aggresive use of polyvalent antivenin for rattlesnake bites result in serious acute side effects ?. West J Med 2001; 175:88-91.

18. Premawardhena AP, de Silva CE, Fonseka MMD, Gunatilake SB, de Silva HJ. Low dose subcutaneous adrenalin to prevent acute adverse reaction to antivenon serum in people bitten by snakes: randomised, placebo controlled trial. BMJ 1999; 318:1041-3.

19. Hui Wen Fan, Marcopito LF, Cardoso JLC, Franca FO, Malaque CMA, Ferrari RA, dkk. Sequential randomised and double blind trial of promethazine prophylaxis againts early anaphylactic reactions to antivenom for bothrops snake bites. BMJ 1999; 318:1451-3.

20. Blaylock RS. Antibiotic use and infection in snakebite victims. South Afr Med 1999; 89:874-6. 